\title{
A CASE OF MULTIPLE PERSONALITY : HYSTERIA OR DEMENTIA PRÆCOX?
}

\author{
BY MARTIN W. PECK, M. D.
}

BOSTON PSYCHOPATHIC HOSPITAL

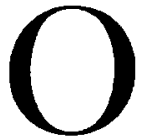

$\mathrm{NE}$ of the shadow lands of psychiatry lies between schizophrenia and the psychoneuroses, and in it are found many perplexing problems in diagnosis. There is reason to believe that where their extremes meet, these relatively malignant and relatively benign conditions are much the same. Both may have a similar etiology and up to a certain point show identical psychogenic mechanisms. In such cases much of the mental effort and diagnostic acumen spent in trying to force a given patient into one group or the other seems futile, and might be better spent in tracing the devious psychological paths over which the psychosis had developed for the purpose of estimating prognosis and determining treatment.

The case presented in this article seemed of interest on account of a mixed clinical picture of major hysterical states and schizophrenic trends. While at no time was the patient accessible to systematic study of the evolution of her disorder, from her behavior and spontaneous conversation a fairly clear understanding could be gained of the conflicts which determined the nature and development of her symptoms.

Miss D., a single woman, thirty-seven years of age, was admitted to the Boston Psychopathic Hospital December 21, 1921, on account of a change in personality developing over the previous four years, with episodic emotional and convulsive phenomena of hysteriform type, culminating in freakish behavior which brought about ridiculous and humiliating situations for the patient and her family.

She was born of Irish parentage and had always lived under the parental roof in the vicinity of Boston. Her family were in moderate circumstances, but the home atmosphere was above the average in refinement and culture for the wage earning class to which she belonged. She was the fourth of nine children, of whom a brother two years her senior and three younger sisters were living. The father had died seven years previously. One sister shared with the patient the apartment of the widowed mother, and another, a married sister, lived in the same house.

In her developmental history she was not considered peculiar or differing excessively from her sisters. She was rather overmodest 
as she grew older, rigid in her adherence to the social conventions, and strict with the younger girls, who considered her oversight Puritanical. Family pride was a dominant feature and she stressed for herself and the others that type of behavior which implied good birth and breeding. She was thoughtful of other people, took more than her share of responsibility in the home and was looked to for advice by both father and mother. She appeared satisfied enough with her life, was gay in spirit and popular with her girl friends, though she had the reputation of being somewhat high-handed. She was busy and active and not given to day-dreaming.

With men she was distant and ill at ease. It was said that at eighteen if she dropped a parcel on the street she would leave it rather than stoop to pick it up if a man were looking on. At home she would not tie her shoe string in the presence of even an intimate family relative. She was thought by her family to have less interest than other young people in the usual type of social life.

She finished the eighth grade in public school at the usual age, and, while not considered backward, she found the work more difficult than did her sisters. She showed no interest in entering high school, though the others all attended several years and she might have done so had she chosen. In religion she was a Catholic and normally devout, showing no overzealousness till the beginning of her present trouble. All her recreations were of a quiet order consisting chiefly in visiting at the houses of friends or entertaining them in her own. She always reported in detail to her mother concerning these activities and was never out late at night. It was said that she had probably never been in a hotel dining-room in her life. She was fond of music and a pianist herself of considerable skill. In reading she preferred a rather virile type of fiction such as tales by Rex Beach and Richard Harding Davis. She was devoted to the Sunday newspapers and had from that source extensive acquaintance with the doings of American society and foreign royalty.

After leaving school she started work as machine operator in a wholesale dressmaking establishment. She was steadily employed till four years before admission, but showed no special ability or ambition and never earned over twelve dollars a week. She had no love affairs as far as the family knew, and only once had any man paid her special attention. That was six years previous and she discouraged his interest.

Her early medical history was not significant. She was con- 
sidered to be in good general health and there were no serious infections. Menstruation was established at sixteen and was regular, with normal flow, but accompanied by considerable pain and sometimes nausea. These symptoms had become less troublesome as she grew older.

Her present illness dated from the summer of 1918. At that time she left work partly because she was tired and nervous and had lost weight, but chiefly to be with her mother and brother on a near-by farm which the latter had purchased for market gardening. She seemed to improve under the out-door life, but in the fall after returning to the city she began to show marked changes of personality. She became thoughtless, irritable and "flighty." She was unruly and antagonistic in her relations to the family, and did odd and impulsive acts in marked contrast to her former conventional behavior. She often left the house suddenly at unseasonable hours and took long walks; she showed some eccentricity in her dress, and intruded in a rather rude way on conversation between others. At times she brought home boxes of candy and ate it all greedily. Again she would sit down to the table before the others and hurry through a meal. She did not appear depressed nor did she shun company except on her solitary walks.

Through the winter of 1918-19 she showed marked zeal in religious matters and went to her church four or five times a day. She also talked of going into a convent. For some months at this time she was obsessed with cleansing rituals, washed her hands "every fifteen minutes" and took a bath several times daily.

On March 10th without warning or known cause, while sitting quietly in the room, she suddenly started screaming and continued for two hours. She made some attempt to get out of an upstairs window and struggled vigorously with members of the family who restrained her. Immediately following this episode she became mute and did not speak for a period of five months. During this time she appeared quite normal in other ways and would occasionally sing though refusing to talk. She helped some with the housework, went out for walks though never unaccompanied, and appeared to enjoy jokes and fun. She read a great deal and accomplished useful sewing. At times she would write notes on request, but seldom completed her theme. In her retrospective account of this period she told her physician that it seemed as though she "both couldn't and shouldn't talk," and that the condition she was in was a "general disorder which 
was going to pass away and I should keep quiet till it did." Her reading at the time was at first mostly in the prayer book, but she gradually gave up her excessive religious interest and also her cleansing ceremonies.

On August 7th a convulsion occurred. The patient was sitting on the porch and was brought an eggnog by her sister. She jumped up quickly, threw the drink over the rail and went inside the house where she lay down on a couch and began to sing. Suddenly she stiffened and became unconscious, remaining so for a period of two hours. The muscular rigidity and a shifting mental contact lasted all the afternoon and evening. Her face was cyanosed at first but there was no biting of the tongue, clonic movements or incontinence. The whole incident was spectacular and alarming, and the family thought she was dying. She slept quietly all night and in the morning her speech had returned. For the week following she seemed perfectly normal in every way, her disposition and conduct conforming to her old habit.

After this week of calm, eccentric behavior reappeared. She made calls on families with whom she had but a distant acquaintance and engaged in animated and intimate conversation. At church instead of entering unobtrusively as of old, she walked down the length of one aisle and back another seeming to enjoy being conspicuous. She continued to take long walks, sometimes in the evening, and was quite defiant if any attempt was made to dissuade her. Sometimes for weeks at a stretch there would be no odd behavior, but the episodes occurred often enough so that the family never knew quite what to expect. She talked a great deal during this period of love and marriage in a joking and rather bold manner, but this type of expression seemed to be confined to her own home and she did not get into any sentimental difficulties.

During the summer of 1920 she again lived with her mother and brother on the farm. She was able to take full charge of housekeeping and marketing, and hospitably entertained considerable company. She was, however, slightly queer in her dress and continued the desire to display herself when in church so that it was the custom for one member of the family to keep hold of her arm while entering or leaving, and to sit between her and the aisle. Throughout the winter of 1920-1921 she got along fairly well at home, but was disagreeable and unreasonable at times, and airy and lofty in her manner. She implied that the reason she did not work was because she was superior to the 
rest of the family and referred to them half seriously and half playfully, as satisfied to be "common."

In June, 1921, she had a second convulsion and was unconscious three hours. When she regained her senses she began talking animated gibberish and continued for some minutes. This was the first evidence of neologistic production. All the following summer she remained quite her normal self except for one short period of gibberish during a thunder storm. In September she had a third and last convulsion and came out of it talking jargon. She was "raving all night" and had to be held in bed.

From that time on she had spells of gibberish talk every day, appearing without evident cause and lasting from a few seconds to a few minutes. Her eccentric and impulsive behavior became worse than ever. Several times she threw objects at her sisters or mother and was childishly antagonistic if crossed in any way. She had taken her symptoms quite lightly up to this time, but now began to show concern over them and begged to be taken to a hospital. October 1 she was admitted to a private sanitarium, which she left without warning after six weeks' stay. While there the most striking thing observed by the physician in charge was her lack of interest and curiosity in her condition. She continued her gibberish talk at intervals, but otherwise fitted in fairly well with the exception of one incident of excitement, when she chased another patient to whom she had taken a dislike, threatening her with bodily harm.

She eloped from the sanitarium apparently without premeditation and walked five miles to her home carrying two grips. She was permitted to remain, and from that time to her admission to the Psychopathic Hospital a month later, she got on quite well except on three occasions, two in church and one in a theatre, when she broke out in excited talk in a manner to cause considerable disturbance. She also took a candle from the church and seemed to have no realization of the violation of etiquette which this act represented. Afterwards in giving her own reason for the theft she said, "It seemed to me all departed souls return to the Catholic Church. I once saw a vision of a cross with all lights around which seemed struggling souls. The candle flickering seemed my own soul." To complicate matters she again insisted on taking evening walks in unfrequented localities and fears were felt for her safety. She appeared worried over her condition and came willingly to the hospital. She told her sister that she "would 
rather be dead than suffer so, to be apparently intelligent, and then go off in a moment like an insane person."

On admission she was quite normal in manner. During physical examination she was over-modest and hyperæsthetic. No abnormalities other than hyperactive tendon reflexes were revealed. Hysterical stigmata were absent. When the routine pelvic examination was attempted by a woman physician, the patient went into a convulsive attack with much struggling and had to be returned to the ward. She was apologetic for this demonstration a few hours later.

Her behavior from the standpoint of ward observation showed three types: a first which was normal; a second one characterized by odd acts; and a third which included episodes of excitement. In the first she was quiet and refined, busied herself in the usual ways and seemed tranquil and satisfied. This phase at the beginning was much less in evidence than the others, but as time went on it took more and more the ascendency, till for six weeks prior to her discharge on April 9, four months after admission, she showed no abnormality to casual observation.

The second type was characterized by such acts as quietly trying the doors of the ward or standing in a constrained manner in out of the way places. At times she was found lying under beds, at others she would be seen on her knees in attitude of prayer. She was careless about exposure of her person, and would lift her skirts high when going over the stairs, or get out of bed improperly covered. If spoken to by nurses she was often pert in reply; with other patients she was ironical, sarcastic and flippant.

The excited periods of the third type varied in intensity and duration. Sometimes she would dance about the ward in extravagant manner but with solemn countenance. Occasionally she attacked other patients in a harmless, hair-pulling way. A few times she ran amuck, leaped over beds, tore down and threw objects around, and fought physicians and nurses, but again seemed to avoid inflicting real injury. On two instances she showed for a day quite typical manic episodes, with elevation of mood and constant motor activity. She was destructive to bedding and clothing and bedecked herself in an outlandish manner. All the incidents of excitement were strongly tinged with the ludicrous. She was often contrite and apologetic, although never humble, following these scenes.

In formal interviews she showed a three-phased personality, changing suddenly from one to another, or presenting shifting com- 
binations of two or all three in kaleidoscopic variety. Phase A was what from her history appeared to be her normal self. She was quietspoken, ladylike and alert; respectful to physicians and appreciative of attention. This phase was difficult to maintain. If other than impersonal matters were broached she shifted to some other state in which she was entirely different.

Phase $\mathrm{B}$ was characterized by the production of neologisms and was striking and spectacular. It always started and ceased abruptly. She would change in a moment from a subdued and reserved individual, if she happened to be in phase A, to an exactly opposite picture. She became animated and vivacious and poured forth a rapid stream of gibberish with abundant and expressive emphasis and with extravagance of gesture and facial expression. These periods lasted from a few seconds to a few minutes, and varied in frequency. At times they recurred so constantly as to make interview impossible, again they occurred only once or twice or not at all. This phase was more apt to arrive if personal matters were under discussion, but it seemed to be precipitated by no special topic or circumstance, and often appeared quite spontaneously. Usually her talk was directed to examiner, but occasionally she seemed quite oblivious to any presence and talked to the empty air as though hallucinating. However, she quite consistently denied afterward that such was the case.

At first owing to the fact that her strange language was so smoothly constructed, it seemed possible it might represent some unfamiliar tongue, but this proved not to be the case. No special meaning could be obtained from the patient for any of the phrases. She would often give a glib interpretation but never was consistent and would as freely give another explanation a few hours later. There was no amnesia for these periods. At times by sharp command she could be brought out of them. Always she could repeat test words which had been given, or remember other incidents of the occasion, even when she paid no attention at the time.

Her own attitude toward phase $B$ was rather superficial. She looked upon this talk as curious and rather boresome, but not as a subject for special concern. In her flippant moods she referred to it as representing the "best part of her nature," and once said, "maybe it is vulgar talk but nobody can understand." This phase after the first two weeks of hospital residence gradually became more infrequent, and disappeared entirely during the last two months.

Phase $\mathrm{C}$ was less standardized and distinct than the other two, 
and presumably may have included several states which were not clearly distinguished. In spite, however, of bursts of excitement and odd acts, the general level of attitude and behavior during this stage was fairly consistent. She was flippant, gay, affectatious, coquettish and showed hosts of mannerisms. She was eager, spontaneous and witty. It was impossible to hold a serious conversation as she refused to stick to the subject and indulged in much ridiculous talk. She always managed to create something of an erotic atmosphere by manner or conversation. She was spirited and stubborn in discussion with physician, and high handed in her relations with nurses and other patients. Much of the mental examination during the first few weeks, and in fact all during her stay, had to be carried on during this phase.

Phase $D$ was seen once or twice the first few days, but did not recur. On those occasions she assumed the appearance of a little child, with whining, shrinking manner and baby-talk.

The patient's stream of talk in phase A was coherent, relevant and pertinent. There was little spontaneity, and it was difficult to get a sequential history, as she tended to wander from the main threads of her life story. She was quite self depreciatory in some respects, referring frequently to her lack of educational and cultural advantages and commenting on the superiority of members of the staff in that regard. She had a superficial knowledge of classic literature and an extensive vocabulary, though often mispronounced words which were otherwise used correctly.

In phase B her talk was usually a steady running rapid stream without break of any sort, a typical glossolalia. Occasionally she stammered and words seemed to stick in her throat. The following is an attempt at phonetic representation. "Anegwan-im-is-whenimisame" (repeating the last several times). "Migitopania-welegasome-polysotanse-onigophoton-ineligovasotomectomy-weheis."

In phase $C$ there was great variation in her utterance. Much of the time it was coherent and rclevant, but given in a vivacious and coquettish, or a simpering and affected way. At other times she was moderately incoherent, and again completely so. There were also illustrations of distractability and flight. On one occasion when in phase $\mathrm{B}$ she was given the stimulus word Columbus, in order to test her power to repeat it later. She immediately stopped the gibberish, changed to stage $\mathrm{C}$ and said, "Columbus, Columbus, Columbus, Isabella, she sold her jewels, you should be a teacher in a boys' school,- 
I'm trying to explain and it seems to be something I'm trying to do, perhaps for my church."

A favorite trick was to turn the conversation to a discussion of the physician, making comment on his personal appearance or general qualities, complimentary and otherwise. At times she made somewhat intimate advances, putting her hand on his knee or seizing the lapel of his coat, but never went beyond these playful familiarities. During the first part of her hospital stay she would suddenly break in on ordinary conversation with entire change of subject, and in high pitched voice, narrate some fanciful tale. While doing so she would often rise from her chair and walk hurriedly about the room, but her manner was always more playful than distressed, and only once did she seem out of touch with her surroundings. The following are examples of these productions: "He killed her on the battle fields of France, he stabbed her from behind." Urged to amplify this theme, she told a disconnected story in breathless haste: "Fourteen people all lived in same house - never anything so wicked or actions so dreadful; invited people there and said do not tell your wife. A good time party, he would never go there again." She became more excited, smiled, frowned, and repeated, "To him, to him," many times, staring as though hallucinated. She rambled on about thirst and pain in the neck, then sang with affected voice. Continuing with the story, she said, "They went to Budapest, then Monte Carlo, she was a peach, he a great big man; she was a love, she is charity. He was a married man; they had a home on Long Island and shooting occurred; it was jealousy. They escaped in a boat from Ireland; he was not justified, she was beautiful. They came back to New York; raised hell in New York; he was a son-of-a-gun, he was captured and freed." She then talked of her admiration for the English people; their vinecovered cottages; their modesty of dress; her respect for Queen Mary. Then she added, "I love Queen Victoria because she loved Albert, I love every one who loves their husband, especially when they have sponge-cake for supper. Do you like sweet potatoes?"

At another time when asked some question about her social life she said in loud voice, "Wine and flowers, shoes and stockings; kisses; home in limousine, dump me in ash can, back yard; footman comes to the door, 'walk in'; Mutt and Jeff are there." Again she watched the physician taking notes for a time, then broke in with, "China, Japan and Austria; you are there scribbling, I am cleaning out the water-closet; I go and play the piano and get the keys all dirty; I like to clean out water-closets." 
One afternoon after a longer period than usual of straightforward discussion, she glanced out of the window at a neighboring house and said, "Blue sky and balconies; Juliette in a balcony, would you play Romeo to my Juliette?" When taken to task for such foolish talk, she responded sharply, "There is nothing foolish about it, Juliette is a human emotion, every woman has it; I have a perfect right to it." She resented being told she could control herself and said, "I've been a devil in a way, I would have liked to jump off." She then added with elaborate sarcasm, "Oh, yes, Miss D" (referring to herself) "is a very quiet girl." She irritably denied having nervous trouble, saying, "I would not change nerves with King George or President Harding; I have attained everything I desired; now let the State use me if it wants to." It was impossible to follow up these topics, the patient always took refuge in change of personality, or in flippancy, coquetry or specious philosophizing.

Once when discussing a vague reference she had made to some special spiritual significance in her experiences, she remarked in ecstatic manner, "Judgment Day has come; it gives me wonderful sensations of the kind I'd like to do manure all over the bed," then added, "married people know better about such sensations." On the topic marriage she again said, "I think marriage is rotten, coarse, vulgar, the worst thing possible, terrible, horrible; but it really must be wonderfully sacred and beautiful or Almighty God would not have created this institution; I think it would be delightful to be married from the waist up." These crude vulgarities were infrequent and in striking contrast to her usual type of talk. Although she constantly drifted to erotic themes her manner and language were, as a rule, not coarse.

Her intellectual functions gave no evidence of any disorder when her attention could be held to the tests, except that on a few occasions she seemed disoriented. At other times she wilfully gave false answers to questions on orientation, but showed in other ways that she was in good contact. Psychometric tests gave a normal mental level.

In mood, she varied from tranquil good humored serenity to swings of gayety and tense hurrying animation, mixed with occasional flashes of defiance and irritability. She never showed depression or anxiety, even when she could be held to a serious consideration of her illness.

Clear cut delusions and hallucinations were difficult to establish at any time while the patient was under observation. There was a history that in the fall of 1918 , just at the beginning of her illness, she 
came home from Boston crying and much upset because people on the street had been talking about her. She reported that they spoke belittlingly of her ancestry, and said "she need not feel so superior." She talked of this matter for a week or so, and then dropped it altogether and no further ideas of reference occurred. She discussed this whole topic freely with physician in retrospection, laughed about it and appeared to have complete insight. She remarked, "I often think how ridiculous it was to feel that way, just crazy."

Detailed examination of the mental content was difficult owing to the inaccessible or flippant states which dominated the clinical picture. It was often impossible to hold her to serious discussion for more than a few minutes at a time. Repeatedly it appeared that distinctly pathological material was present only to have it vanish in thin air when carefully followed out. She related a number of hallucinatory episodes, mostly of religious significance, and each sharply circumscribed. In describing one which occurred six years previously, she said, "I heard sweet little voices, they may have been angel's voices, they may have been imaginary, I was not awake, I heard them calling and answered and said I was coming." She also told of a vision when a woman came to her bed one night while she was suffering from the tooth-ache, put her arms around her and cured her swollen jaw. She commented, "If this was a dream it was the realest one anybody ever had." She also told of waking in the night some years before, bathed in perspiration and finding the bed clothes pulled down from her shoulders. She implied some man may have visited her, but denied any body sensations or other evidence of attack. These incidents were always told in the same way and there was no attempt to elaborate them. The patient herself seemed to attach to them only minor importance.

She at times vaguely admitted some hallucinatory experiences during her periods of excitement, but never became specific, saying, "It is something that can't be explained, a side to everybody that belongs only to the self." By her manner she appeared to be referring to the intuitive or spiritual side rather than to crude sense deceptions.

In addition to these fragmentary phenomena, throughout all study and observation one consistent trend of thought persisted, namely, that she was in some way marked out for special spiritual purpose. At times she discussed this topic with nearly complete insight, again she showed rather crude delusions of saintship and special destiny, all of it obscured and distorted by flippancy and fabri- 
cation. A dream which she had just before her father's death seven years before, played an important part in this system of ideas and she frequently referred to it. In the dream she was riding on a trolley-car with her father. They came to a lake, across it the sun was setting; she left her father and started home on foot; she seemed to be next in a large music hall; suddenly the roof opened and white-robed figures on white horses came drifting through; she felt it must be Judgment Day. She stated that at times she looked upon this dream as of great importance, at others she felt it was foolish. In discussing this theme, several times she connected her father with God, and said, "Why was he in it" (the dream) "he was an insignificant person; he was a good man, probably had a wonderful soul, but he had no education and polish." Once she said, "If my father was God, he did not know his business very well. I wonder if there are two Gods, yours and mine, one for those of polish and culture."

On one occasion she said petulantly, that she regretted having the dream, it bothered her conscience, and added, "My conscience seems to be all there is of me at times." She told how her church had taught her that the most important thing on earth was to save the immortal soul; she had heard of saints that had been canonized on account of visions or dreams, and implied that she herself might be marked for saintship. "Me or my father," was the answer she once made to a direct question, and continued, "I am willing to wait till I am eighty years old."

She said one day that her impulses to do strange things came direct from Almighty God, "He makes a fool of me as far as the world is concerned but does the world understand God as I do:" She then laughed and retracted her statement, saying, "I don't understand any better than you do, but I have a faith and trust that all things are done by Him." At another time she said with positiveness that either God or Madam Curie were making changes in the world (with reference to herself): "If it's radium it's Madam Curic, if it's electricity, it's me." At this interview she implied some electrical feelings in her body, chiefly in relation to the pelvis, but never brought up the matter again or would admit it on questioning.

In one of her serious moods she remarked, "It is a positive fact that I see what others do not of the hereafter; it gives perfect happiness, but do you know what it has cost me, a lot of suffering during these last two years; I am grateful enough to spend half my time on my knees." In similar mood she said, "I had rather be groping around 
like other people than to have my eyes wide open; I did not want it, I could save my soul like other people."

Repeated attempts were made during the last part of her hospital stay to bring about some insight concerning the psychogenic mechanisms operating in the production of her symptoms. This was apparently unsuccessful although she showed no lack of friendship or respect in these interviews. She either skillfully evaded such discussion or spiritedly contradicted physician's statements, maintaining that all her symptoms were due to physical causes, or implying that there was some purpose in them beyond the comprehension of any other person.

She emphatically refused hypnotic treatment, saying that she "had to fight the devil every minute of the day and did not want any more trouble." She was reluctant to discuss her dreams, giving sometimes as a reason that she did not wish to corrupt physician's morals.

During the early part of March she for the first time expressed herself as hopeful of getting well and referred to her condition as, "crazy, foolish sickness." There still remained a buoyant, roguish gayety and peculiar, sharp humor to all her attitudes. Queer behavior of minor order persisted to the last. One day she removed part of her waist and sat about with arms bare to the shoulder. On another she wore a cape with flaming green lining wrong side out. She once with perfect solemnity handed a physician an empty envelope, saying it was pay for his services. Two weeks before discharge she referred to the cross she had to bear, said it was a cross of flowers, "a sweet cross even if a good deal of filth in it." Then laughing, she said, "It is God's will, however, and I don't mind following the divine will after I have sowed my wild oats." She continued, saying that up to seven years before her mind dwelt on purity, then a sudden change came and she thought of evil things, "a pig pen was clean compared to me." She stated that she then changed from a "young giddy thing," to an old woman, and ever since had been swinging from one extreme to the other, "not able to obtain the poise of middle age."

Sex history brought out nothing of special importance on the objective side. She talked fairly frankly on the subject. Some instruction was received from her mother and she acquired other information in the usual way, without special conflict or morbid curiosity. She denied auto-erotism or other sex experience, saying she had impure thoughts at times, but otherwise had "done nothing wrong." She did not admit any sex passion, and showed no interest 
whatever in the subject of maternity. She volunteered various opinions on the subject of relationships between the sexes, saying she did not believe in kissing a man till the engagement ring had been produced, and then only once or twice before marriage; commenting humorously that otherwise a girl might lose him. She then added rather sharply, "I don't know if it is necessary for me to tell you if I ever sat on a man's lap."

At one interview she gayly confided, "Since five years old I have had a fatal weakness for men. I would like to be a butterfly and light for a moment on everybody's head." At another time she spoke of thinking of marriage and of "getting relief by wandering off into other realms"; and continued, "It seems as though I would go mad thinking of such things." In talking of a minor love affair occurring six years before, she said, "It seemed I was not to be anybody's wife, but should go on alone; it gave me great happiness; a feeling as though one had come to a new life in sympathy with the world and a very small place would do."

A lack of self-consciousness was at all times a striking feature of her demeanor. She was noticeably unaffected in both her calm and excited moods by the manner and opinions of nurses and other patients. In her relations with physicians she never showed embarrassment, humiliation or chagrin.

Some additional information concerning family history and relationships was divulged as time went on by the patient, and corroborated rather reluctantly by the sisters. The maternal grandfather belonged to the group of landed gentry in Ireland. He was an eccentric, bookish man, and married rather late in life a young woman of good character but uneducated and of lowly station. This match was opposed by his father and resulted apparently in a permanent estrangement. The patient's mother was brought up in comparative luxury and was well educated. She in turn married a man much beneath her in the social scale, a farm laborer with little education. The patient said her father was chosen because he was the best looking man in the village.

The young couple were thrown on their own resources and emigrated to the United States before any of the children were born. They appear to have been quite happy together, at least there was never any serious discord. The father was periodically alcoholic and lost some positions on that account. During the patient's early years he was employed on a large private estate in the country and she observed 
in that way something of life on the upper social level. Later on he was employed in unskilled positions in machine shops.

The patient while under observation showed the greatest admiration for her father. She referred many times to his fine looks, his physical strength and manliness. She said he had a harsh side and a gentle side, and the children were always a little in awe of him, although he left discipline chiefly to the mother. He was never in any sense a chum of his daughters and relations were always formal. He was a religious man although he never spoke of this subject to the family. During his later years he spent at least an hour each evening in solitary prayer. The patient laughingly remarked that, when drunk, he took a rosary to bed with him, and added, "He was something of a sport in his day." Other members of the family said that he looked to the patient for advice and counsel and by no means dominated her.

The mother was described as a quiet gentle little woman, quite strict and holding her daughters up to high standards in every respect. One of the sisters said, "Nothing we could do except the very best could satisfy her." She and the patient were always on good terms, but never intimates.

The only brother, two years older than the patient, was very bright in school, obtained a scholarship at Georgetown University and was ambitious to succeed in the law. Owing to some sort of nervous breakdown, he was forced to give up his education and content himself with a quite humble station. He never married. His sister expressed admiration for him only second to that for her father, and when in her obstinate and irritable states he had more influence than anybody else.

\section{SUMMARY AND FORMULATION OF CASE}

As is evident from the foregoing account, it was difficult to analyze and clarify this case. The patient herself was an uncertain and unreliable source of information. The whole clinical picture was scattering and fragmentary, and beyond some general topics the trends of thought and interest were elusive. However, it seemed possible to construct a working hypothesis from the material available, which was of value in establishing order and unity.

The conflicting elements of human nature present in all individuals were excessively marked in this patient from childhood, and developed into two strongly diverging groups of tendencies. Finding insurmountable difficulty in integrating these opposing trends into a satisfactory whole; one of the groups was selected as her official personality 
and as far as possible everything not in harmony with it was repressed. For many years she maintained this personality on the surface, permitting her family and friends, perhaps even herself, no inkling of what was going on underneath.

She was quiet, home-loving, dutiful and strict in the conventions. With men she was shy and retiring. There was present at all times an exaggerated pride with feelings of family superiority together with strivings for social and cultural levels beyond possibility of achievement. These ambitions did not prevent an appearance of satisfaction with her life as a girl and young woman, although she later referred to an underlying discontent during those periods. No doubt her feelings were in part determined by her knowledge of the social standing of her ancestors on her mother's side. A natural timidity, lack of special abilities and a rather rigid bringing-up, together with her strict religious standards, aided in holding her to the humdrum life of home and shop.

The repressed side of her nature was full of longings for excitement, adventure and romance, with desires for the flesh-pots and high places. Not all was tranquility beneath her calm exterior. According to her own story she went through a series of violent attachments to various men, the beginning at a tender age marked by an affair with the butcher's boy. In all cases she worshipped from afar and the objects of her adorations were never aware of them.

She stated that in her girlhood she could never consult a physician in his office as other girls did because she felt, "I might think he wished me to sit on his lap." In her twenties she developed a habit of painfully blushing if addressed by men, being noticeable even in relation to shop foremen and others whose proximity she could not well avoid. The excessive prudishness and modesty point of course to compensatory expressions for opposite tendencies of equal vigor. The undue religious activity and obsessive cleansing rituals shown for a period may be looked upon as the symbolic staging of an acute struggle with what she considered were unworthy and impure desires.

At times in fancy she consorted with the mighty. She devoured the Sunday supplements dealing with society and royalty, and said, "On Sunday especially, I live with the elect of the world and roam far from my shed and kitchen."

On the objective level she was able to get along with these insecure adjustments until shortly after her father's death. Coupled with this bereavement was her advance toward middle age with the consequent waning of the hope that better and more glorious things might come 
into her life. Here were new difficulties to adjustment, and opportunity was given for the repressed side of her nature, systematized into something of a personality in itself, to break through the repressing forces and find expression, albeit a distorted one. Phases B and C appearing during her psychoses may be interpreted as dissociated manifestations of this other personality. It is interesting to note that she seemed to those around her much happier after the alternating personality states were once well established.

The marked ambivalent attitude toward sex matters, with obsessive interest on the one hand, and exaggerated repugnance on the other, needs more than a superficial explanation. Cause for such a condition could reasonably be ascribed to past experiences of a sexual nature which had assumed a place in the total personality highly charged with conflicting emotions. Another possible factor from the standpoint of Freudian psychology would be some interruption or twist in psycho-sexual development, resulting in the necessity for facing adult sex problems with immature emotional attitudes. If the history in her case, of complete freedom from objective sex episodes be accepted at its face value, then a reason may be found in the second alternative. Some incestuous attribute to her love-life in the way of a father fixation would furnish an explanation. There is much in the patient's relation to her father to bear out this hypothesis. Her excessive admiration and sense of awe, her emphasis on the significance of the dream in which he figured, the vague feeling that he might in some way be identified with the Deity, and the beginning of her symptoms shortly after his death all seem significant.

One ominous feature stood out in what would otherwise be a benign clinical picture. The patient showed a persistent tendency to look upon herself as specially marked by Divine favor, perhaps chosen for saintship, and at times regarded her symptoms as a series of trials for body and soul preparatory to that position. The looseness of this delusional system, and the absence of any but episodic hallucinations were mitigating features. At the same time the development of such ideas in order to give a satisfying justification for her conflicts and difficulties, denoted that a dangerous compensatory mechanism was in operation.

In spite of a degree of improvement which has permitted her return to factory work for the time being, prognosis must be considered far from certain. The seeming impossibility of aiding her in gaining insight, together with her strong resistances and persistent refusal to 
1 face the facts of the situation, are not favorable. On the other hand it may be hoped that if satisfying work, recreation and service be established as an outlet for her love interests, the passage of time will dull the intensity of the instinctive fires which burn within, and give an increasing serenity for meeting the prosaic life which lies before her.

This case has been discussed on the assumption that psychogenic factors were alone responsible for the pathology. Such an assumption is not wholly warranted. The problem remains as to whether the dissociation, and reintegration in the form of new personalities was related to deeper lying organic processes. If the latter, was the organic process primary, and simply co-operative in the sense of permitting the dissociation and resynthesis, or were the organic changes induced by the functional conflicts? Such questions must for the present remain unanswered. 